\title{
POLLINATION ECOLOGY OF RHYNCHOSIA HEYNEI WIGHT AND ARN. (LEGUMINOSAE), AN ENDEMIC MEDICINAL HERBACEOUS SHRUB SPECIES OF PENINSULAR INDIA
}

\section{A. J. Solomon Raju and K. Venkata Ramana}

Journal of Institute of Science and Technology

Volume 22, Issue 2, January 2018

ISSN: 2469-9062 (print), 2467-9240 (e)

Editors:

Prof. Dr. Kumar Sapkota

Prof. Dr. Armila Rajbhandari

Assoc. Prof. Dr. Gopi Chandra Kaphle Mrs. Reshma Tuladhar

JIST, 22 (2): 32-44 (2018)

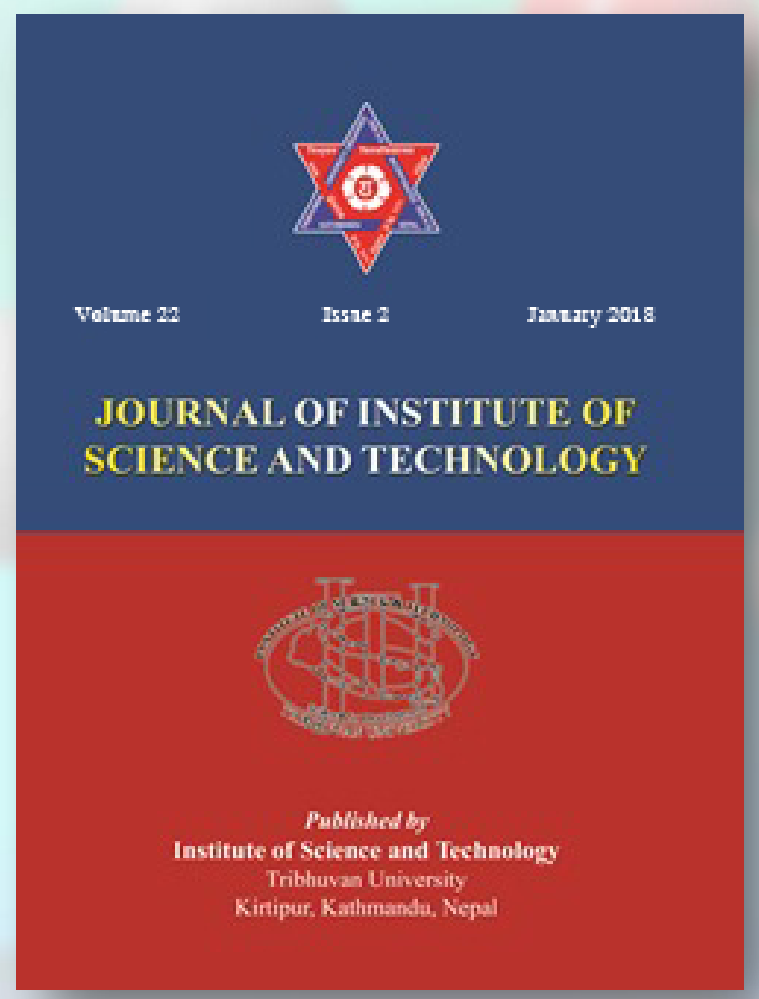

Published by:

Institute of Science and Technology

Tribhuvan University

Kirtipur, Kathmandu, Nepal 


\title{
POLLINATION ECOLOGY OF RHYNCHOSIA HEYNEI WIGHT AND ARN. (LEGUMINOSAE), AN ENDEMIC MEDICINAL HERBACEOUS SHRUB SPECIES OF PENINSULAR INDIA
}

\author{
A. J. Solomon Raju ${ }^{1 *}$ and K. Venkata Ramana ${ }^{2}$ \\ ${ }^{I}$ Department of Environmental Sciences, Andhra University, Visakhapatnam 530 003, India \\ ${ }^{2}$ Department of Botany, Andhra University, Visakhapatnam 530 003, India \\ ${ }^{*}$ Corresponding E-mail: solomonraju@gmail.com
}

Received: 28 November, 2016; Revised: 8 September, 2017; Accepted: 10 September, 2017

\begin{abstract}
Rhynchosia heynei is an endemic shrub in dry deciduous forests of peninsular India. It is medicinally important and used locally for the treatment of different diseases. Despite its medicinal value and endemic status, no studies were made on the pollination ecology of this shrub to understand the factors leading to its endemic status. In this connection, the standard protocols were followed for the systematic study of the pollination in the Nallamalai forest of Eastern Ghats of Andhra Pradesh. The study indicated that the plant produces nectariferous bisexual flowers. The flowers were self-compatible and equipped with explosive pollination mechanism adapted for melittophily. The fruit set occurred through self and cross-pollination. Mature and dry pods dehisce explosively to disperse seeds. Regeneration occurred through perennial root stock and seeds during rainy season but the regeneration rate is poor due to rocky and dry habitat with little moisture and nutrient content.
\end{abstract}

Keywords: Bisexuality, Bees, Fruiting, Pods, Regeneration.

\section{INTRODUCTION}

Rhynchosia (Family Leguminosae, Tribe Phaseoleae and Sub-tribe Cajaninae) consists of approximately 200 species and occurs in both the eastern and western hemisphere in warm temperate and tropical regions (Grear, 1978; Lackey, 1981; Jayasuriya, 2014). In the Eastern Ghats of India, Madhava Chetty et al. (2008) reported twelve species of this genus distributed in the Seshachalam hills of southern Eastern Ghats of Andhra Pradesh. They include $R$. beddomei, R. rufescens, $R$. suaveolens, $R$. cana, $R$. albiflora, $R$. capitata, $R$. courtollensis, $R$. densiflora, $R$. heynei, $R$. minima, $R$. rothii, $R$. rufescens, $R$. suaveolens and $R$. viscosa. Of these, $R$. beddomei is a rare and endemic medicinal species and restricted to few areas in Seshachalam hills of Chittoor District, Andhra Pradesh (Nair \& Sastry, 1998; Pullaiah, 2006). Bakshu \& Venkata Raju (2009) stated R. heynei as an endemic medicinal plant species found in the forests of Eastern Ghats of India. Chadburn (2012) noted that $R$. heynei is an endemic species in peninsular India. Rawat et al. (2001) stated that the natural habitat of $R$. heynei has been degraded or cleared to a great extent in the Deccan thorn scrub forest and Central Deccan Plateau dry deciduous forest eco-regions. The most serious threats are from overgrazing, cattle encroachment into forests, forest clearance, particularly for fuel wood, and conversion of land to agriculture. The conservation status of these eco-regions was changed from endangered to critical state due to threats from the human population. $R$. heynei has been noted to be 'rare' by Ahmedullah \& Nayar (1986) and 'occasional' by Pullaiah \& Ramamurthy (2001). Population data is currently not available for this species. In this context, Rawat et al. (2001) noted that surveys are needed to establish the current population status and trends, and also the habitat status and threats, to determine any specific conservation measures that are needed for this species. Bakshu \& Venkata Raju (2009) reported that $R$. heynei is a medicinal plant and is used by local people to treat rheumatic pains, arthritis and skin diseases. In this context, the knowledge of 
the reproductive ecology of $R$. heynei is required to take measures for its conservation and management, and also for exploring the possibilities to restore and expand the distribution range in the dry deciduous forest ecosystems of peninsular India.

Franco (1995) provided floral details of Rhynchosia in Brazil. He reported that it is autogamous which is limited by spatial segregation between stigma and anthers. Levels of out-crossing are maintained by the retention of a pollination mechanism. Hypanthidium sp. and Centris sp. are the primary pollinators and the pollen is deposited on the ventral part of their abdomen when the flower is probed. Craufurd \& Prins (1979) reported that Rhynchosia sublobata is self-compatible and pollinated by Xylocopa bees. Etcheverry et al. (2011) reported that Rhynchosia edulis and $R$. senna var. texana display valvular pollination mechanism; the former is facultative xenogamous while the latter is obligately xenogamous. There is no information on flowering phenology, breeding systems, pollen presentation mechanisms, pollination mechanisms, pollinators and fruiting ecology of any species of Rhynchosia. With this backdrop of pollination studies and the importance of $R$. heynei as an endemic medicinal plant species, the present study was undertaken to provide the details of its pollination ecology to understand the factors contributing to its present status.

\section{MATERIALS AND METHODS}

\section{Study site}

The study region is an integral part of Southern Eastern Ghats of Andhra Pradesh in Peninsular India. The area is a part of Nallamalai Range in Kurnool District and located at $16^{\circ} 07^{\prime} \mathrm{N}$ latitude and $78^{\circ} 86^{\prime} \mathrm{E}$ longitude (Figure 1). The entire region represents the dry deciduous scrub forest ecosystems. The site is characterized by a combination of rocky, undulating terrain with black soil. In this area, Rhynchosia heynei is found in small patches and widely scattered individuals in shaded areas. The plants grow from rocky cracks, crevices and caves which contain moisture due to accumulation of completely or partially decomposed organic matter.

\section{Flowering and floral biology}

Flowering season was defined based on regular field trips made. Twenty inflorescences were tagged and followed to record the length of flowering and the number of flowers produced. Anthesis was initially recorded by observing twenty five marked mature buds in the field. Later, the observations were repeated five times on different days in order to provide accurate anthesis schedule. Similarly, the mature buds were followed for recording the time of anther dehiscence. The presentation pattern of pollen was also investigated by recording how anthers dehisced and confirmed by observing the anthers under a 10x hand lens. The details of flower morphology such as flower sex, shape, size, colour, odour, sepals, petals, stamens and ovary were described based on twenty five flowers randomly collected from five plants. Observations regarding the position and spatial relationships of stamens and stigma in mature bud, at anthesis and during the flower-life with reference to self and/or cross-pollination were made very carefully.

\section{Pollen output}

Thirty mature but un-dehisced anthers from five different plants were collected and placed in a Petri dish. Later, each time a single anther was taken out and placed on a clean microscope slide $(75 \times 25$ $\mathrm{mm}$ ) and dabbed with a needle in a drop of lactophenol-aniline-blue. The anther tissue was then observed under the microscope for pollen, and if pollen grains were not present, the tissue was removed from the slide. The pollen mass was drawn into a band, and the total number of pollen grain was counted under a compound microscope $(40 \times$ objective, $10 \times$ eye piece $)$. This procedure was followed for counting the number of pollen grains in each anther collected. Based on these counts, the mean number of pollen produced per anther was determined. The mean pollen output per anther was multiplied by the number of anthers in the flower for obtaining the mean number of pollen grains per flower. The characteristics of pollen grains were also recorded.

\section{Pollen-ovule ratio}

The pollen-ovule ratio was determined by dividing the average number of pollen grains per flower by the number of ovules per flower. The value thus obtained was taken as pollen-ovule ratio (Cruden, 1977).

\section{Nectar characters}

The presence of nectar was determined by observing the mature buds and open flowers. The average volume of nectar per flower was determined and expressed in $\mu$ l based; for which ten flowers were used. The flowers used for this purpose were bagged at mature bud stage, opened 
after cessation of nectar secretion and nectar was squeezed into micropipette for measuring the volume of nectar. Nectar sugar concentration was determined using a Hand Sugar Refractometer (Erma, Japan). Ten samples were used for examining the range of sugar concentration in the nectar. For the analysis of sugar types, paper chromatography method described by Harborne (1973) was followed. Nectar was loaded on Whatman No. 1 of filter paper along with standard samples of glucose, fructose and sucrose. The paper was run ascending for 24 hours with a solvent system of n-butanolacetone-water (4:5:1), sprayed with aniline oxalate spray reagent and dried at $120^{\circ} \mathrm{C}$ in an electric oven for 20 minutes for the development of spots from the nectar and the standard sugars. The sugar types present and also the most dominant sugar type were recorded based on the area and colour intensity of the spot. The sugar content/flower was expressed as the product of nectar volume and sugar concentration per unit volume, $\mathrm{mg} / \mu \mathrm{l}$. This was done by first noting the conversion value for the recorded sugar concentration on the refractometer scale and then by multiplying it with the volume of nectar/flower. Table 5.6 given in Dafni et al. (2005) was followed for recording the conversion value to mg of sugars present in one $\mu 1$ of nectar.

\section{Stigma receptivity}

In visual method, the stigma physical state (wet or dry) was considered to record the commencement of receptivity. $\mathrm{H}_{2} \mathrm{O}_{2}$ test as given in Dafni et al. (2005) was followed for the confirmation of stigma receptivity period.

\section{Breeding Systems}

Mature flower buds of some inflorescences on different individuals were tagged and enclosed in paper bags. They were tested in the following way and the number of flower buds used for each mode of pollination is given in Table 2 .

1. The flowers were fine-mesh bagged without hand pollination for autonomous autogamy.

2. The stigmas of flowers were pollinated with the pollen of the same flower manually by using a brush; they were bagged and followed to observe fruit set in manipulated autogamy.

3. The emasculated flowers were hand-pollinated with the pollen of a different flower on the same plant; they were bagged and followed for fruit set in geitonogamy.
4. The emasculated flowers were pollinated with the pollen of a different individual plant; they were bagged and followed for fruit set in xenogamy.

All these categories of flower pollinations were followed for fruit set. If fruit set was present, the percentage of fruit set was calculated for each mode.

\section{Flower-visitors}

The flower foragers included only bees. The hourly foraging visits of bee species were recorded on 3 or 4 occasions depending on the possibility and the data was tabulated to use the same for further analysis. Fully blooming plants were selected to record the foraging visits of bees. The data obtained was used to calculate the percentage of foraging visits made by each bee species per day. Their foraging behaviour was observed on a number of occasions for the mode of approach, landing and probing behaviour, the type of forage collected and contact with essential organs to result in pollination, inter-plant foraging activity in terms of cross-pollination.

\section{Determination of pollen carryover efficiency of bees}

Ten specimens of each bee species were captured from flowers and brought to the laboratory. Each specimen was washed in ethyl alcohol, stained with aniline-blue on a glass slide and observed under microscope to count the number of pollen grains present. The average number of pollen grains carried by each species was calculated to know the pollen carryover efficiency.

\section{Natural fruit set, seed dispersal and seedling} ecology

A sample of flowers on twenty five plants were tagged on different plants prior to anthesis and followed for fruit set and seed set rates in openpollinations. Fruit maturation period, fruit dehiscence, seed dispersal and germination aspects were observed to the extent possible.

\section{Photography}

Plant habitat, flowering inflorescences, and flower and fruit details were photographed with Nikon D40X Digital SLR (10.1 pixel) and TZ240 Stereo Zoom Microscope with SP-350 Olympus Digital Camera (8.1 pixel). Olympus Binoculars (PX35 DPSR Model) was also used to make field observations. Magnus Compound Microscope - 5x, $10 \mathrm{x}, 40 \mathrm{x}$ and $100 \mathrm{x}$ magnification was used for studying the pollen characteristics. 

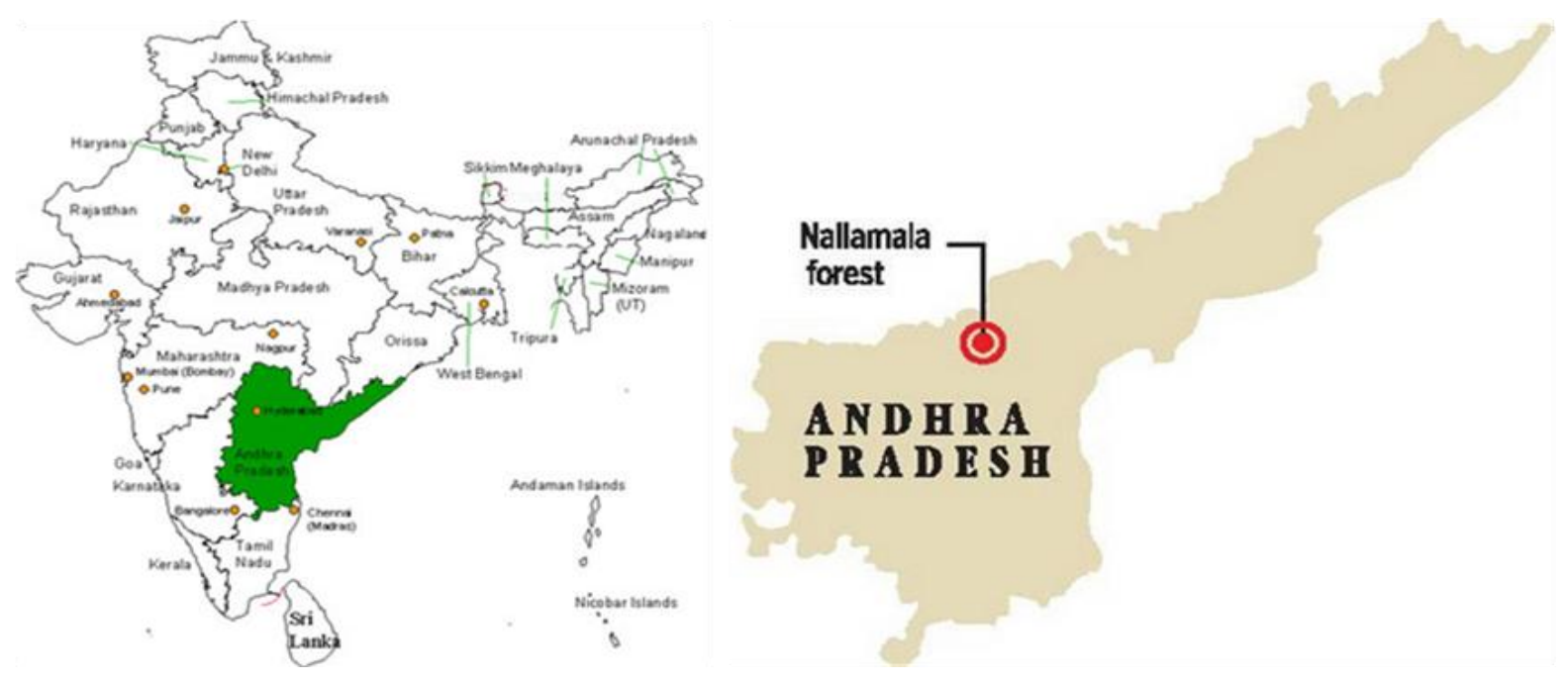

Fig. 1. Map showing study area in Andhra Pradesh, India.

\section{RESULTS}

\section{Phenology}

It is a perennial erect hairy herbaceous shrub with slender velvety branchlets. It grow in shaded areas (Figure 4a). The plant re-grows from below ground perennial root stock and from the seed during JuneSeptember during which growth and leaf flushing occurs. The leaflets are trifoliate with reticulate venation and leaflets are petiolate, elliptic to oblong-ovate, coriaceous, pubescent above and velvety beneath. The flowering occurs during September-January with peak flowering in November (Figure 4b, c). The plants wither and disappear in March-April. The inflorescence is a lax raceme, pedunculate (30 $\mathrm{mm}$ long), borne in leaf axils, 50-60 mm long with variable number of flowers 6-20.

\section{Flower morphology}

The flowers are pedicellate ( $3 \mathrm{~mm}$ long), small (13.6 $\pm 0.9 \mathrm{~mm}$ long and $15.8 \pm 0.7 \mathrm{~mm}$ wide), yellow, odorless, papilionaceous, zygomorphic and bisexual. The calyx is green with yellow tinge and consists of 5 free, lanceolate, acuminate, pubescent, $13 \pm 1.1$ $\mathrm{mm}$ long and $3.8 \pm 0.6 \mathrm{~mm}$ wide sepals. The corolla is yellow, slightly pubescent, specialized and consists of upper standard petal, two wing petals and two keel petals. The standard petal is large $(10 \pm 0.6$ $\mathrm{mm}$ long and $6.7 \pm 0.4 \mathrm{~mm}$ wide), scarlet red lines inside at the bottom which serves as nectar guide; the petal base is clawed and consists of two inflexed fingernail auricles. The standard petal envelops the rest of the petals in bud but reflexes when the flower blooms. The two adjacent petals $(9.1 \pm 0.4 \mathrm{~mm}$ long and $2.8 \pm 0.4 \mathrm{~mm}$ wide) called wing petals surround the two bottom petals, called keel petals $(8.2 \pm 0.3$ $\mathrm{mm}$ long and $2.9 \pm 0.2 \mathrm{~mm}$ wide). The keel petals form a proximal cylindrical part and a distal part consisting of a pressed angular pouch, with an acute porate tip in which the stamens and stigma are housed. The keel and the wing petals are attached by means of two notched folds. The wing petals serve as alighting platform for insects visiting the flowers. The stamens are ten, $4.7 \pm 0.4 \mathrm{~mm}$ long, diadelphous; nine filaments are fused by the basal part into a sheath open along the upper side while the tenth filament is free and lies on the others. The distal parts of the filaments are free and contain $1.3 \pm$ $0.4 \mathrm{~mm}$ long uniform dithecous anthers. The ovary is sessile, green, densely pubescent, $2 \mathrm{~mm}$ long and lies in the sheath of the filaments along the cylindrical part of the keel (Figure 4h-k). It is monocarpellary and monolocular with two ovules arranged on marginal placentation (Figure 41). It has a long filiform style with a capitate wet shiny stigma, with both together accounts for a length of $7 \mathrm{~mm}$. The stigma is situated almost at the height of the anthers. The distal portion of free filaments and style and stigma are incurved and clamped into the keel petals.

\section{Floral biology}

Mature buds open during 1030-1430 h with peak anthesis during 1130-1230 h (Table 1). Unfolding of the standard petal and wing petals indicates flowering opening. The keel petals do not unfold and remain in their original position as in mature bud stage (Fig. 4dg). All the ten anthers in a flower dehisce at the same time by longitudinal slits in mature bud stage. The number of pollen grains per anther is $885.2 \pm 59.36$ and per flower are 8,852. The pollen-ovule ratio is 
4,426:1. The pollen grains are monads, spheroidal, $31.37 \pm 4.7 \mu \mathrm{m}$ in size, powdery and tricolporate, angulaperturate with reticulate exine (Figure 4i). A nectariferous disc is present at the base of the ovary. The initiation of nectar secretion occurs during mature bud stage and its cessation occurs an hour after anthesis. Individual flowers produce $1.2 \pm 0.06 \mu \mathrm{l}$ of nectar with $0.42 \mathrm{mg}$ of sugar. The nectar sugar concentration is $31 \%$ (Range 29-33\%) consisting of sucrose, glucose and fructose with the first as dominant. Nectar is deeply concealed and it is open through two windows between the joined and the free filaments at the flower base. These windows allow access to the nectar. The stigma attains receptivity during anthesis and remains receptive for about three hours. After three hours of anthesis, the standard, wing and keel petals gradually move close to each other enclosing the reproductive organs (Fig. 4m). The closed flowers remain so even during most part of the fruit development. The calyx initially encloses the ovary and subsequently turns light brown and discloses the ovary since the latter gradually bulges and develops into a seeded pod.

Table 1: Anthesis as a function of time in Rhynchosia heynei.

\begin{tabular}{ccc}
\hline Time (h) & $\begin{array}{c}\text { No. of flowers } \\
\text { anthesed }\end{array}$ & $\begin{array}{c}\text { Percentage of } \\
\text { Anthesis }\end{array}$ \\
\hline 0830 & 0 & 0 \\
0930 & 0 & 0 \\
1030 & 8 & 10 \\
1130 & 31 & 40 \\
1230 & 23 & 30 \\
1330 & 11 & 15 \\
1430 & 4 & 5 \\
1530 & 0 & 0 \\
\hline
\end{tabular}

No. of mature buds tagged: 77

\section{Pollination mechanism}

The reproductive column is held under pressure within the keel part in open flowers and it is exposed when the pollinator presses against the wing and the keel petals. When bees land on the wing petals, the latter cause the keel petals to release the reproductive column explosively. Consequently, the reproductive column snaps forward against the standard petal causing most of the pollen to be instantly released and the pollen thus released comes into contact with the ventral side of the bee body. Since the incurved stigma is situated above the height of the anthers, it strikes the bee body first due to which crosspollination occurs. If the bee has visited other flowers previously and carried pollen on its ventral side, then also the pollen ejected from the anthers powders the ventral side of the insect instantly. If it is the first visit of the bee to the flower, then it effects self-pollination upon explosive release of reproductive column from the keel boat. With the departure of the bee from the flower, the reproductive column does not return back to its former position but the keel moves forward partly covering the stamens and stigma. The downward movement of keel petals occurs in each subsequent foraging visit by appropriate bees. Tripping of keel boat can also occur due to heavy rain or high temperature that weakens turgidity of the restraining keel tissues. But, the tripping due to these two factors is ruled out since the plant flowers during winter season when heavy rains do not normally occur and the temperature usually stands low. If the flower is untouched or tripping to keel did not occur, the reproductive column is never exposed and remains enclosed in the keel boat. Such flowers fall off subsequently upon withering without fruit set.

\section{Breeding systems}

In mature buds, anthers dehisce but autonomous autogamy does not occur. Fruit set is absent in unmanipulated autogamy, $15 \%$ in hand-pollinated autogamy, $63 \%$ in geitonogamy, $76 \%$ in xenogamy and $78 \%$ in open-pollination (Table 2).

Table 2: Results of breeding systems in Rhynchosia heynei.

\begin{tabular}{lccc}
\hline \multicolumn{1}{c}{ Pollination mode } & $\begin{array}{c}\text { No. of flowers } \\
\text { pollinated }\end{array}$ & $\begin{array}{c}\text { No. of fruits } \\
\text { formed }\end{array}$ & Fruit set (\%) \\
\hline Autogamy (un-manipulated and bagged) & 25 & 0 & 0 \\
Autogamy (hand-pollinated and bagged) & 40 & 9 & 15 \\
Geitonogamy & 60 & 38 & 63 \\
Xenogamy & 70 & 53 & 76 \\
Open-pollination & 450 & 351 & 78 \\
\hline
\end{tabular}


Table 3: Natural fruit/seed set rate in Rhynchosia heynei.

\begin{tabular}{|c|c|c|c|c|c|c|c|c|c|}
\hline \multirow[b]{2}{*}{$\begin{array}{c}\text { No. of } \\
\text { flowers } \\
\text { sampled }\end{array}$} & \multirow[b]{2}{*}{$\begin{array}{c}\text { No. of } \\
\text { flowers } \\
\text { set } \\
\text { fruit }\end{array}$} & \multirow[b]{2}{*}{$\begin{array}{c}\text { Fruit } \\
\text { set } \\
(\%)\end{array}$} & \multirow[b]{2}{*}{$\begin{array}{c}\text { Seed } \\
\text { set } \\
(\%)\end{array}$} & \multicolumn{6}{|c|}{ Rate of seed set/fruit } \\
\hline & & & & $\begin{array}{c}\text { No. of } \\
1- \\
\text { seeded } \\
\text { fruits }\end{array}$ & $\begin{array}{c}1- \\
\text { seeded } \\
\text { fruit set } \\
(\%)\end{array}$ & $\begin{array}{c}\text { No. of } \\
2- \\
\text { seeded } \\
\text { fruits }\end{array}$ & $\begin{array}{c}2- \\
\text { seeded } \\
\text { fruit set } \\
(\%)\end{array}$ & $\begin{array}{c}\text { No. of } \\
\text { seedless } \\
\text { fruits }\end{array}$ & $\begin{array}{l}\text { Seedless } \\
\text { fruits }(\%)\end{array}$ \\
\hline 450 & 351 & 78 & 89 & 62 & 18 & 282 & 80 & 7 & 2 \\
\hline
\end{tabular}

\section{Bee pollinators and pollination}

The flowers were exclusively foraged by bees for pollen and nectar. They showed foraging activity during 0930-1630 h with peak activity during 1130$1230 \mathrm{~h}$ (Figure 2). The bees included Apis florea, Ceratina sp. (Figure 4n) (Apidae) and Halictus (Figure 4o) (Halictidae) (Table 4); they were regular and consistent foragers throughout the flowering season. Individually, A. florea made $36 \%$, Ceratina $32 \%$ and Halictus $32 \%$ of total foraging visits (Figure 3 ). They tripped the flowers while foraging for nectar/pollen and effected pollination. The bees landed on the wing petals and the keel, with their head near the standard. They then exerted a certain pressure with legs on the wing petals until these and the keel bent downwards, and then proceeded to collect nectar during which the bee's abdomen appeared pollen smothered (sternotribic pollen deposition). To collect pollen, the bees took "U" turn after nectar collection and proceeded to the stamens to collect pollen. The bees were found to visit the same flowers on the same and different plants several times during the day and such a foraging activity was considered to be promoting cross-pollination rate. The body washings of bees showed that they carried pollen ranging from 329 to 689 (Table 5) indicating that they are effective pollen carriers.

Table 4: List of insect foragers on Rhynchosia heynei.

\begin{tabular}{|c|c|c|c|c|c|c|c|}
\hline Order & Family & Sub-family & Genus & Species & $\begin{array}{l}\text { Common } \\
\text { Name }\end{array}$ & $\begin{array}{l}\text { Foraging } \\
\text { schedule }\end{array}$ & $\begin{array}{c}\text { Forage } \\
\text { Collected }\end{array}$ \\
\hline \multirow[t]{3}{*}{ Hymenoptera } & Apidae & Apinae & Apis & $\begin{array}{l}\text { florea } \\
\text { F. }\end{array}$ & Dwarf bee & 0930-1630 & $\begin{array}{l}\text { Nectar }+ \\
\text { Pollen }\end{array}$ \\
\hline & & Xylocopinae & Ceratina & sp. & $\begin{array}{l}\text { Small } \\
\text { carpenter } \\
\text { bee }\end{array}$ & 0930-1630 & $\begin{array}{l}\text { Nectar + } \\
\text { Pollen }\end{array}$ \\
\hline & Halictidae & Halictinae & Halictus & sp. & Sweat bee & 0930-1630 & $\begin{array}{l}\text { Nectar + } \\
\text { Pollen }\end{array}$ \\
\hline
\end{tabular}

Table 5: Pollen recorded in the body washings of bee foragers on Rhynchosia heynei.

\begin{tabular}{lcccc}
\hline Insect species & $\begin{array}{c}\text { Sample size } \\
(\mathbf{N})\end{array}$ & Range & Mean & S.D \\
\cline { 3 - 5 } & 10 & $329-478$ & 418.8 & 48.71 \\
\hline Apis florea & 10 & $462-689$ & 581.5 & 543.4 \\
Ceratina sp. & 10 & $391-673$ & 85.18 & 103.74 \\
Halictus sp. & & &
\end{tabular}




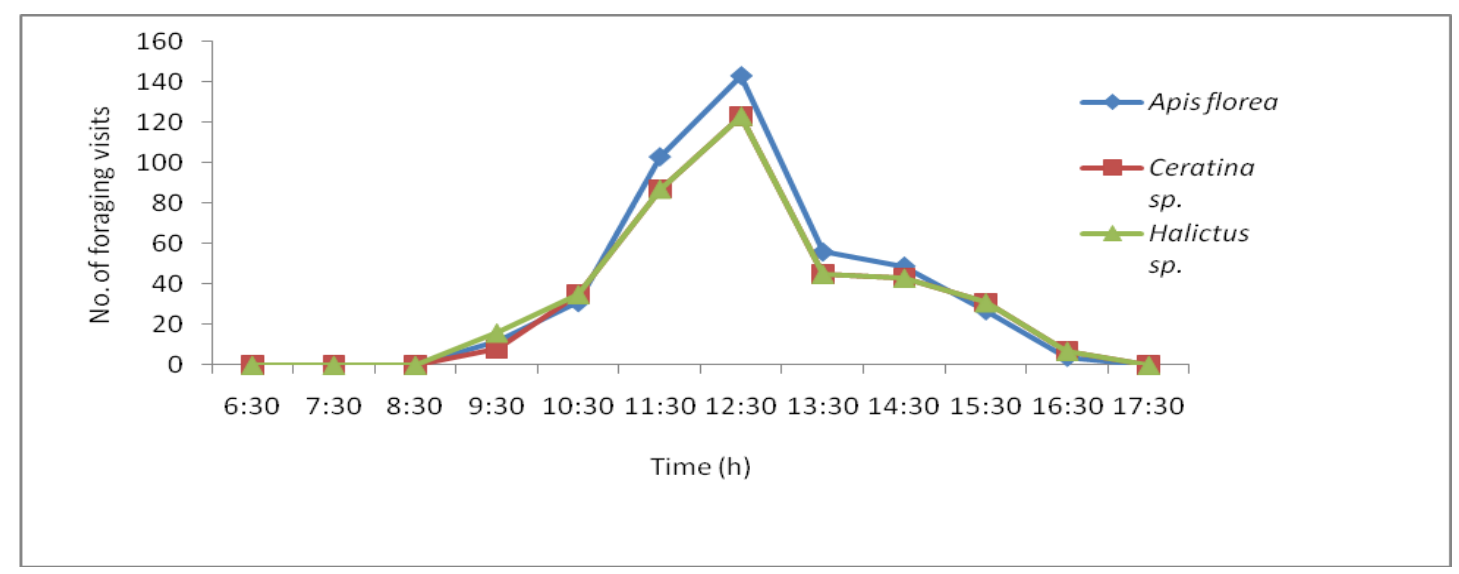

Fig. 2. Hourly foraging activity of bees on Rhynchosia heynei.

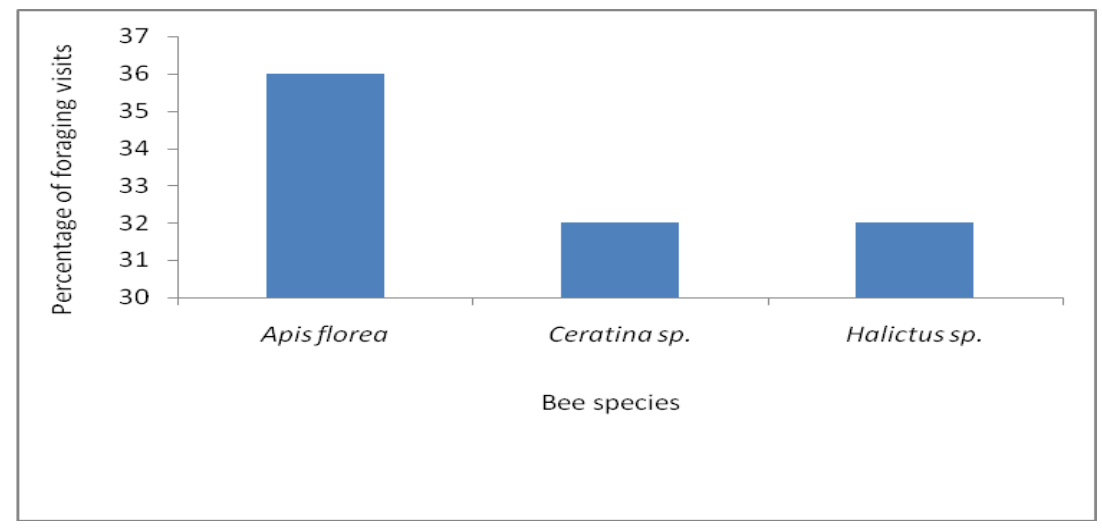

Fig. 3. Percentage of foraging visits of individual bee species on Rhynchosia heynei.

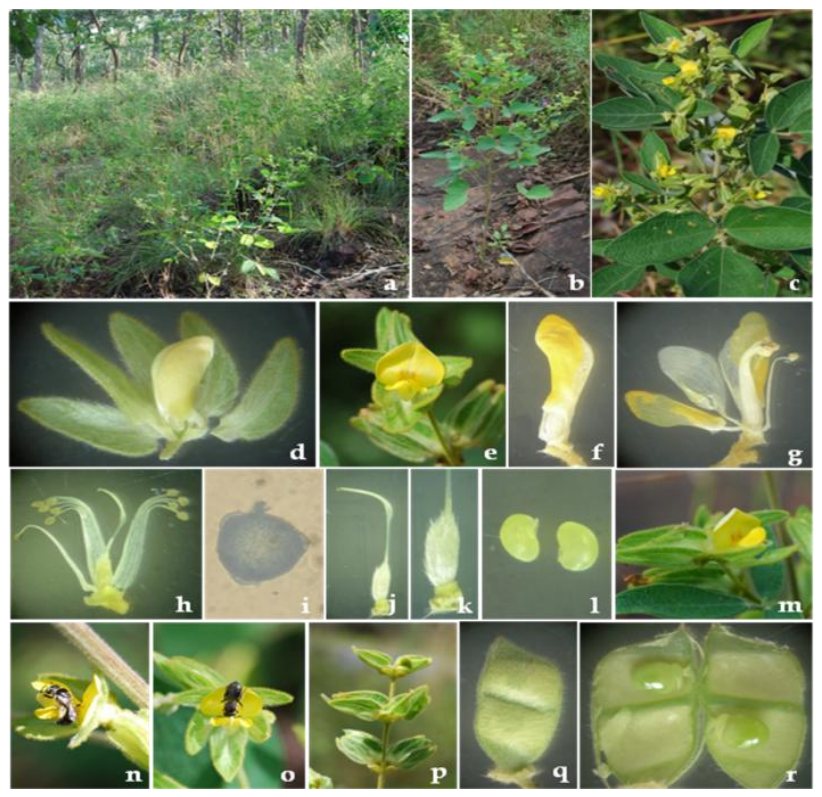

Fig. 4. Rhynchosia heynei: a. Habitat, b. Individual plant in flowering, c. Flowering branches, d. Mature bud, e. Flower, $f$. Keel and wing petals, $g$. Keel and wing petals together with released stamens and stigma, h. Gynoecium enclosed in the staminal sheath, $i$. Pollen grain, J. Ovary, style and stigma, $k$. Ovary with hairy surface, l. Ovules, $m$. Partially closed flower, $n$. Ceratina sp., o. Halictus sp., p. Fruits with persistent calyx, q. \& $r$. Fruits with 2 seeds. 


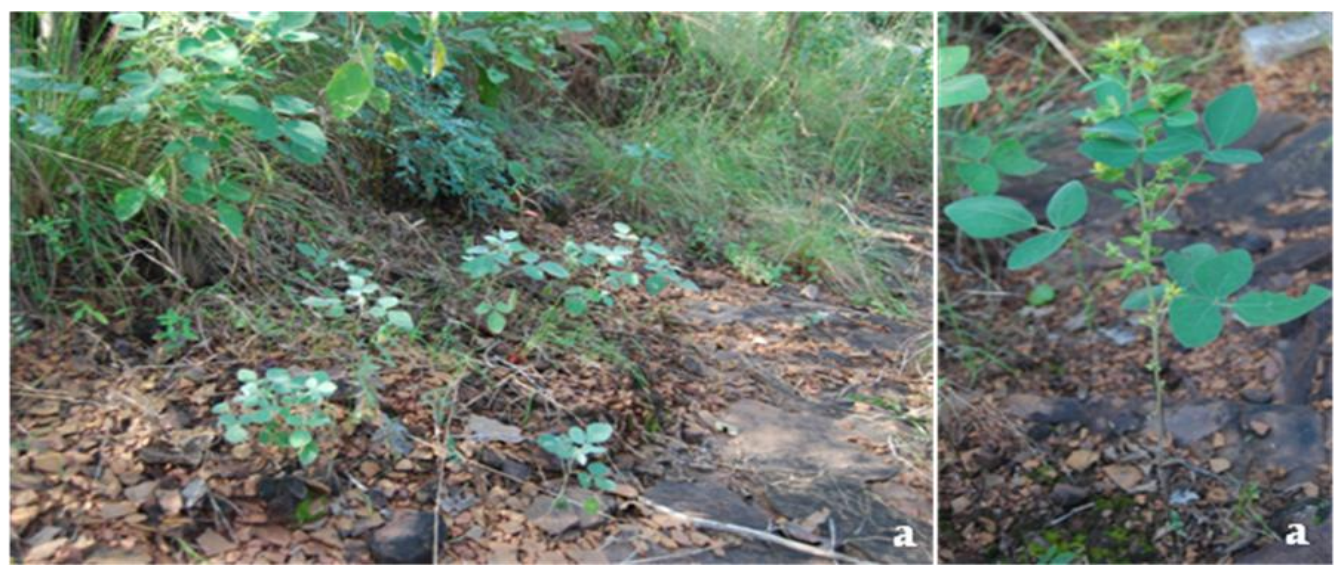

Fig. 5. Rhynchosia heynei: a. \& b. Seed germination and seedling establishment.

\section{Fruiting behavior}

The fruit growth and development begins immediately after pollination and fertilization. The fruits mature within three weeks. The sepals enclose the growing fruit initially and the fruit emerges out of the sepals gradually with its gradual growth and development (Figure 4p). Fruit is green initially and brown when ripe and dry. It is a nonfleshy, pubescent, oblong, $13.1 \pm 0.9 \mathrm{~mm}$ long, 5.5 $\pm 0.4 \mathrm{~mm}$ wide, compressed and obliquely septate. The pods mostly produced two seeds (Figure 4q,r) while a few produce one seed. Fruit set without seeds also exist but it is negligible. The fruit set rate in open-pollination mode is $78 \%$ out of which 2 -seeded pod set rate is $80 \%, 1$-seeded pod set rate is $18 \%$ and seedless pod set rate is $2 \%$. Total seed set rate is $89 \%$ (Table 3).

\section{Seed ecology}

Mature and dry fruits display explosive dehiscence to disperse seeds. The pod with bi-valvate configuration dehisces to eject the seed. The seed is grayish brown, reniform, finely pubescent, $3.6 \pm$ $0.5 \mathrm{~mm}$ long, $2.8 \pm 0.6 \mathrm{~mm}$ wide, and strophiolate. Seeds germinate during rainy season which starts from June onwards. Seedlings grow continually but their growth rate is subject to the availability of moisture status of the soil in rocky crevices/cracks/caves (Figure 5a, b). In the areas where soil is sufficiently moist, seeds continue growth and produce mature plants within two months and subsequently commence flowering and fruiting.

\section{DISCUSSION}

Rhynchosia heynei is endemic to peninsular India (Chadburn, 2012). It is reported to occur in mixed and dry deciduous forests (Pullaiah \& Ramamurthy,
2001). The present study shows that $R$. heynei occurs in rocky shaded areas in Nallamalai dry deciduous forest areas of Eastern Ghats of Andhra Pradesh. It occurs as small populations or as widely dispersed individuals intermingled with other herbaceous or grass species shaded by tree cover. As a perennial erect shrub, it grows from seed as well as from perennial root stock during rainy season. The flowering season is well defined and is almost confined to winter season. Individual plants produce a moderate number of flowers during their life time due to production of a few inflorescences and each of which produces a minimum of 6 and a maximum of 20 flowers. Individual flowers are prominent by their pedunculate lax racemose inflorescences bearing distinct yellow flowers against the foliage.

In $R$. heynei, hermaphroditic sexual system is functional due to production of fertile pollen grains and functional ovary. The flowers display the near synchronous hermaphroditism or homogamy due to the occurrence of anther dehiscence in mature bud stage and receptivity of stigma during anthesis. The entire reproductive column stays inside the keel petals even after anthesis; in this situation, there is a likelihood of the occurrence autonomous autogamy. But, hand-pollination tests indicated that autonomous autogamy does not occur despite selfcompatibility but it is functional when this mode of pollination is manipulated by brushing the stigma with its own pollen. Such a situation suggests that the flowers are essentially dependent on flower foragers for fruit set through self- as well as crosspollination. It appears that the stigma although receptive blocks the germination of the self-pollen while it is in keel petals and hence, it essentially requires the rupture of its surface by a pollinator to allow the self - or cross pollen to germinate. Such a 
stigmatic regulatory function appears to have evolved to discourage selfing and promote outcrossing. Shivanna \& Owens (1989) stated that the rupture of the stigmatic surface by pollinator permits the pollen to germinate in the flowers of Phaseoleae members with thick stigmatic cuticle. On the contrary, Castro \& Agullo (1998) reported that in Vigna, a member of the tribe Phaseoleae, autonomous self-pollination may occur by spontaneous rupture of the stigmatic membrane. Similar stigmatic surface that prevents selffertilization has also been reported in Vicia faba (tribe Vicieae) (Lord \& Heslop-Harrison, 1984) and in Medicago scutellata (tribe Trifolieae) (Krietner $\&$ Sorensen, 1985); however, in these species autofertile lines have been reported to have thin stigmatic cuticles allowing spontaneous disruption and self-fertilization. In $R$. heynei, the stigmatic surface appears to have thick cuticle and does not have the mechanism of causing spontaneous rupture to facilitate autonomous self-pollination. In effect, the tripping of keel petals appears to be essential to cause rupture on the stigmatic surface by the tripping agent due to which there is more likelihood of the occurrence of either geitonogamy or xenogamy. The fruit set rates recorded in handpollinated geitonogamy and xenogamy also substantiate that the plant is facultative xenogamous, a breeding system that is flexible and keeps the options open for both selfing and outcrossing mediated by pollen vectors.

Schrire (1989) stated that the ecological and evolutionary success of Leguminosae has been related to biotic pollination mechanisms. The three sub-families within this family have achieved a characteristic floral architecture, in which plants within the sub-family Papilionoideae have developed the most complex floral mechanisms. Plants within the Papilionoideae have zygomorphic flowers that are mainly bee-pollinated (Westerkamp, 1997); although bird pollination and bat pollination has also been recorded within the subfamily (Ortega-Olivencia et al., 2005). In beepollinated flowers of Papilionoideae, it is assumed that each part of the corolla is specialized for a particular role in pollinator attraction and the success of pollination. The flag or standard petal attracts pollinators; the keel protects androecium and gynoecium and, together with the wings, provides a platform for the insects to land on. The wings also operate as levers that raise or lower the keel (Stirton, 1981). The flowers typical of pollination by the bee family Apidae are zygomorphic, bright yellow or blue with nectar guides, and frequently with hidden rewards such as those in the Lamiaceae, Scrophulariaceae, Fabaceae and Orchidaceae (Faegri \& van der Pijl, 1979). In the present study, the Fabaceae member, $R$. heynei has papilionaceous corolla with flag, wing and keel petals; the flag petal serves as a visual attractant, wing petals provide landing platform and keel petals protect the entire reproductive column. The flowers are typical of pollination by bees since they are zygomorphic, standard petal with nectar guide, hidden nectar at the corolla base and hidden pollen in keel petals.

Within the sub-family Papilionoideae, primary and secondary pollen presentations have been reported. In plants with primary pollen presentation, pollen is delivered directly from the anthers to the vector's body. In plants with secondary pollen presentation, pollen grains are delivered first on a floral part such as the keel petals in Papilionoideae and then on the body of the vector implying an accurate delivery of pollen on the vector's body (Howell et al., 1993). These two pollen presentation patterns are associated with the four types of basic pollination mechanisms - valvular, pump, explosive and brush, all of them are associated with a particular floral architecture and kinetics. In the valvular type, pollen presentation is primary, whereas in the other three mechanisms, it is secondary (Yeo, 1993). In the explosive mechanism, commonly only one pollination event occurs and it has evolved independently in several tribes (Small, 1988), while in the other three mechanisms, repeated visitation is possible (Westerkamp, 1997). In the present study, $R$. heynei flowers have explosive pollination mechanism and deliver pollen directly from the anthers to the bee's body when keel petals are tripped by the foraging bee; this type of pollen delivery is the representative of primary pollen presentation associated with explosive pollination mechanism. In the flowers, the staminal column is held under pressure within the keel, and when the tension is released by the forager, the same column snaps forward against the standard petal causing all the pollen to be instantly released. The reproductive column remains exposed and does not return back to its original state but the keel petals return back partially covering the stamens and stigma. The efficiency of explosive pollination mechanism depends on the ambient weather conditions, especially temperature and relative humidity. Since $R$. heynei flowers during winter season, it accordingly commences anthesis from 
late morning onwards, by which time the ambient air will be relatively dry and hence is conducive for the efficient functioning of the explosive pollination mechanism. Further, the bees also commence their foraging activity as soon as the flowers open and continue forage collection until the flowers close back. The concealment of the stamens within the keel petals until it is tripped is an advantage for the plant to secure pollen from unusual rains and ambient moisture conditions during the flowering season of this plant (Peter et al., 2004).

Percival (1961) stated that plants with deep-tubed flowers tend to produce sucrose-rich nectar, whereas those with open or shallow-tubed flowers tend to be hexose-rich. Baker \& Baker (1983) stated that flowers with long corolla tube possess more sucrose in their nectar while those with short tubes possess more hexoses in their nectar. In the present study, $R$. heynei with short corolla tube presents sucrose-rich nectar because the nectar is perfectly concealed and hence is not exposed for the breakdown of sucrose into hexoses. Concealment of nectar in this species is adaptive to protect against microorganisms, particularly yeasts, whose metabolic activities dramatically change nectar chemistry and the plant gains a benefit from keeping the nectar as sterile as possible to maintain control over its chemical composition in order to maximize pollination rate by attracting appropriate pollinators (Herrera et al., 2008). Honey bees prefer the flowers with sucrose as chief constituent of nectar (Kevan, 1995). The flowers pollinated by long-tongued bees produce sucrose-rich nectar (Baker \& Baker, 1990). In line with this, R. heynei with melittophilous pollination syndrome also produces sucrose-rich nectar which is utilized exclusively by long-tongued bees. Apis, Ceratina and Halictus bees recorded on this herb have been documented as long-tongued bees (Cruden et al., 1983; Roubik, 1992; Roubik, 2006). Bee-flowers tend to produce small volume of nectar with higher sugar concentration than the nectar of flowers pollinated by other animals (Opler, 1983; Cruden et al., 1983). Honey bees prefer sugar concentration of 20 to $40 \%$ in the nectar (Waller, 1972). On the contrary, Baker \& Baker (1983) noted that honey bees prefer sugar concentration of 30 and $50 \%$ in the nectar. The honey bees have the ability to regurgitate liquid onto concentrated or even crystallized nectar, in this way, reduce its concentration so that it may be imbibed. The preferred sugar concentrations of nectar by other categories of bees have not been found in the literature. But, Pyke \& Waser (1981) stated that the nectar sugar concentration of flowers pollinated by bees is generally higher than that of those pollinated by butterflies and hummingbirds; beepollinated flowers tend to produce nectar with sugar concentration more than $35 \%$ while butterfly or hummingbird pollinated flowers tend to produce nectar with sugar concentration ranged between 20 and $25 \%$. In line with these reports, the present study shows that the flowers of $R$. heynei produce a small volume of nectar with $31 \%$ sugar concentration. Further, the energy yield from nectar appears to be in tune with the requirement of energy by bees. Therefore, $R$. heynei flowers with explosive pollination mechanism, primary pollen presentation, and hidden nectar and pollen have evolved to discourage other foragers from visiting the flowers and to ensure that the bees get the floral rewards. Accordingly, the flowers were pollinated exclusively by bees. The pollinating bees make multiple visits to the same flowers in quest of more pollen and nectar due to which pollination rate is enhanced. In line with this, natural fruit set rate recorded for $R$. heynei is the highest.

Cruden (1977) used the pollen-ovule (P/O) ratios as indicators of breeding systems of plants. He provided $\mathrm{P} / \mathrm{O}$ ratios for different breeding systems $168.5+22.1$ for facultative autogamy, $798.6+87.7$ for facultative xenogamy and $5859.2+936.5$ for xenogamy. Several workers followed these P/O ratios to classify breeding systems of the plant species studied by them. Arroyo (1981) stated that the $\mathrm{P} / \mathrm{O}$ varies according to the pollination mechanism within Papilionoideae. These authors suggested that the plants with explosive mechanism have a low $\mathrm{P} / \mathrm{O}$ because a single pollinator visit is needed for efficient transference of pollen; this low $\mathrm{P} / \mathrm{O}$ is a consequence of the highly specialized, irreversible pollination mechanism, which allows only one effective exchange of pollen with pollinators. Small (1988) stated that Medicago species of the tribe Trifolieae with explosive pollination mechanism displays the lowest pollenovule ratios. Lopez et al. (1999) recorded explosive pollination mechanism with highest pollen-ovule ratios in certain genera of the Fabaceae such as Cytisus, Pterospartum, Teline, Ulex, Stauracanthus and Cytisophyllum. Etcheverry et al. (2011) stated that the Fabaceae plants which they studied with explosive pollination mechanism had intermediate pollenovule ratios. These authors mentioned that 
Rhynchosia edulis and $R$. senna var. texana have valvular pollination mechanism with primary pollen presentation. Both the species are classified as obligate xenogamous based on $\mathrm{P} / \mathrm{O}$ ratio but $R$. edulis has been found to be facultative xenogamous in hand-pollination tests. Craufurd \& Prins (1979) reported that $R$. sublobata is self-compatible and facultative xenogamous in hand-pollination tests; it is pollinated by Xylocopa bees. In the present study, $R$. heynei showed highest $\mathrm{P} / \mathrm{O}$ ratio when compared to that of facultative xenogamy used by Cruden (1977). The highest $\mathrm{P} / \mathrm{O}$ ratio in this plant species appears to be a consequence of pollen collection activity by bees. Therefore, it is inevitable for $R$. heynei to produce high $\mathrm{P} / \mathrm{O}$ to compensate the pollen loss caused by pollen collectors and ensure the function of its vector-dependent facultative xenogamous breeding system.

Tran \& Cavanagh (1984) reported that in Leguminosae, seeds of many taxa exhibit physical dormancy due to the presence of a water impermeable seed coat. With this dormancy, they remain viable for a long period of time. Ali et al. (2012) reported such physical dormancy in Rhynchosia capitata due to which this species is successful as a weed. Shaukat \& Burhan (2000) described seed characteristics and the factors regulating germination of $R$. minima in Pakistan; it exhibits differential success in different habitats with different micro-climates. Rangaswamy \& Nandakumar (1985) reported that the seed coat of Rhynchosia minima is composed of three gradative barriers to water uptake - a surface deposit of waxy material interfused with a lipoidal substance, $\beta$ sitosterol; a subjacent $3-\mu \mathrm{m}$ adcrustation of hemicellulose-cellulose complex; and a layer of palisade cells in which the secondary walls are impregnated with arabinan and the lumen contains tannin and phenolic compounds. The micropyle and hilum function as hygroscopic valves when seed coat breaks open. In $R$. heynei, seeds exhibit physical dormancy during dry season and respond to rainfall during wet season. Many seeds germinate in the vicinity of or away from the parental plants during rainy season but their continued growth are related to soil moisture and nutrient status. Since the plant is a perennial, its underground root stock also produces new growth during rainy season, flowers and fruits during winter season. In Rheynei, the explosive pod dehiscence does not spread the seeds far away from parental sites but rain water causes the seeds to disperse to new places. Therefore, $R$. heynei is not a very widespread species and is exclusively an inhabitant of rocky shaded areas of Nallamalai forest. The seedlings struggle to grow with the simultaneous luxurious growth of local grasses and certain other herbaceous flora. It is pertinent to state the report of Chadburn (2012) that more than 80 per cent of the natural habitat in the Deccan thorn scrub forest and Central Deccan Plateau dry deciduous forest eco-regions, from where $R$. heynei has been recorded, has been degraded or cleared. The most serious threats in these regions include overgrazing, cattle encroachments into forests, forest clearance, particularly for fuel wood, and conversion of land for agriculture. Further, this author also stated that no population data is currently available for $R$. heynei and hence there is an urgent need to carry out surveys to establish the current population status and trends, and also habitat status and threats, to determine any specific conservation measures that are needed. Further, $R$. heynei is used by local people to treat certain diseases (Bhaskshu \& Venkata Raju, 2009). The impact of its use as a medicinal plant on the population status as well as habitat status is to be quantified in order to take effective conservation measures.

Remanandan (1981) stated that Rhynchosia, being closely related to the genus Cajanus, some of its species can be used to provide substantial contributions towards crop improvement in pigeon pea. Furthermore, some species of Rhynchosia have been experimented in India to provide physiological resistance against insect pests such as pod-borer and pod-fly in pigeon pea. In this study, the seeds of $R$. heynei have not been infested by any pod-borer or pod-fly suggesting that they have physiological resistance against insect pests. Therefore, intensive and extensive research is suggested to identify and select desirable genotypes of $R$. heynei that give physiological resistance against pod or seed pests in order to use them for crop improvement in pigeon pea or other legumes.

\section{REFERENCES}

Ahmedullah, M. and Nayar, M. P. (1986). Endemic plants of the Indian Region. (Peninsular India). Vol. 1. Botanical Survey of India, Howrah, pp. 261.

Ali, H. H.; Tanveer, A. and Nadeem (2012). Evaluation of some seed dormancy breaking methods on germination of Rhynchosia capitata (Roth DC). Pakistan Journal of Weed Science Research, 18: 423-432. 
Arroyo, M. T. K. (1981). Breeding systems and pollination biology in Leguminosae. In: R.M. Polhill and P.H. Raven (eds) Advances in Legume Systematics. Part 2. Royal Botanical Gardens, Kew, London, pp. 723769.

Baker, H. G. and Baker, I. (1983). Floral nectar sugar constituents in relation to pollinator type. In: C.E. Jones and R.J. Little (eds). Handbook of Experimental Pollination Biology. Scientific and Academic Editions, New York, pp. 117-140.

Baker, H. G. and Baker, I. (1990). The predictive value of nectar chemistry to the recognition of pollinator types. Israel Journal of Botany, 39: 157-166.

Bhakshu, L. M. and Venkata Raju, B. R. R. (2009). Chemical composition and in vitro antimicrobial activity of essential oil of Rhynchosia heynei, an endemic medicinal plant from Eastern Ghats of India. Pharmaceutical Biology, 47: 1067-1070.

Castro, M. A. and Agullo, M. A. (1998). Anatomy of the stigma of Vigna adenantha (G. F. Mayer) Marechal. Mascherpa and Stainer (Leguminosae, Papilionoideae). Biocell, 22: 9-18.

Chadburn, H. (2012). Rhynchosia heynei. The IUCN Red List of Threatened Species 2012: http://dx.doi.org/10.2305/IUCN.UK.2012.RL TS.T19892259A20134626.en.

Craufurd, R. Q. and Prins, W. H. (1979). Munkolo (Rhynchosia sublobata), a promising pasture legume for Zambia. Tropical Grasslands, 13: 45-52.

Cruden, R. W. (1977). Pollen-ovule ratios: a conservative indicator of breeding systems in flowering plants. Evolution, 31: 32-46.

Cruden, R. W.; Hermann, H. M. and Peterson, S. (1983). Patterns of nectar production and plant-pollinator co-evolution. In: B. Bentley and T. Elias (eds). The Biology of Nectaries, Columbia University Press, New York, pp. 80-125.

Dafni, A.; Kevan, P. G. and Husband, B. C. (2005). Practical Pollination Biology. Enviroquest Ltd., Canada, pp. 590.

Etcheverry, A. V.; Aleman, M. M.; FigueroaFleming, T.; Lopez-Sphar, D.; Gomez, C. A., Yanez, C. et al. (2011). Pollen: ovule ratio and its relationship with other floral traits in Papilionoideae (Leguminosae): an evaluation with Argentine species. Plant Biology (Stuttg.), 14: 171-178.

Faegri, K. and van der Pijl, L. (1979). The Principles of Pollination Ecology. Pergamon Press, Oxford, pp. 244.

Franco, A. L. M. (1995). Pollination ecology and reproductive biology of seven species of Phaseoleae (Fabaceae), Campinas, SP. Ph. D. Thesis, University of Campinas, pp. 123.

Grear, J. W. (1978). A revision of the New World species of Rhynchosia (LeuminosaeFaboideae). Memoirs of New York Botanical Garden, 31: 1-168.

Harborne, J. B. (1973). Phytochemical methods. Chapman and Hall, London, pp. 288.

Herrera, C. M.; Garcia, I. M. and Perez, R. (2008). Invisible floral larcenies: microbial communities degrade floral nectar of bumble bee-pollinated plants. Ecology, 89: 23692376.

Howell, G. J.; Slater, A. T. and Knox, R. B. (1993). Secondary pollen presentation in angiosperms and its biological significance. Australian Journal of Botany, 41: 417-438.

Jayasuriya, A. H. M. (2014). Rhynchosia velutina, a critically endangered legume crop wild relative in Sri Lanka. Ceylon Journal of Science (Biological Sciences), 43: 147-150.

Kevan, P. G. (1995). Bee botany, pollination, foraging and floral calendars. In: P. G. Kevan (ed). The Asiatic hive bee: Apiculture, Biology and role in Sustainable Development in Tropical and Subtropical Asia. Enviroquest Ltd., Ontario, pp. 113-116.

Kreitner, G. L. and Sorensen, E. L. (1985). Stigma development and the stigmatic cuticle of Medicago scutellata. Canadian Journal of Botany, 63: 813-818.

Lackey, J. A. (1981). Phaseoleae. In: R. M. Pohill and P. H. Raven (eds.). Advances in Legume Systematics. Vol. 1, Royal Botanical Garden, Kew, Richmond, England, pp. 301-327.

Lopez, J.; Rodriguez-Riano, T.; Ortega-Olivencia, A.; Devesa, J. A. and Ruiz, T. (1999). Pollination mechanisms and pollen-ovule ratios in some Genisteae (Fabaceae) from Southwestern Europe. Plant Systematics and Evolution, 216: 23-47.

Lord, E. and Heslop-Harrison, Y. (1984). Pollen and stigma organization in Leguminosae: stigma organization and the breeding system of Vicia faba. Annals of Botany, 54: 827-836. 
Madhava Chetty, K.; Sivaji, K. and Rao, T. (2008). Flowering plants of Chittoor District, Andhra Pradesh, India. Students Offset Printers, Tirupati, pp. 490.

Nair, M. P. and Sastry, A. R. K. (1998). Red Data Book of Indian Plants. Botanical Survey of India, Calcutta, pp. 644.

Opler, P. A. (1983). Nectar production in a tropical ecosystem. In: B. Bentley and T. Elias (eds.). The Biology of Nectaries, Columbia University Press, Columbia, pp. 30-79.

Ortega-Olivencia, A.; Rodriguez-Riano, T.; Valtuena, F. J.; Lopez, J. and Devesa, J. A. (2005). First confirmation of a native birdpollinated plant in Europe. Oikos, 110: 578590.

Peter, C. I.; Dold, A. P.; Barker, N. P. and Ripley, B. S. (2004). Pollination biology of Bergeranthus multiceps (Aizoaceae) with preliminary observations of repeated flower opening and closure. South African Journal of Science, 100: 624-628.

Pullaiah, T. (2006). Biodiversity and conservation with special reference to Eastern Ghats. Proc. Nat. Conf. on Forest Biodiversity Resources: Exploitation, Conservation and Management, CBFS, Madurai Kamraj University, Madurai.

Pullaiah, T. and Sri Rama Murthy, K. (2001). Flora of Eastern Ghats - Hill Ranges of South East Asia. Volume 2. Leguminosae (Fabaceae). Regency Publications, New Delhi, pp. 383.

Pyke, G. H. and Waser, N. M. (1981). The production of dilute nectars by hummingbird and honeyeater flowers. Biotropica, 13: 260-270.

Rangaswamy, N. S. and Nandakumar, L. (1985). Correlative studies on seed coat structure, chemical composition, and impermeability in the legume Rhynchosia minima. Botanical Gazette, 146: 501-509.

Rawat, G. S.; Desai, A.; Somanathan, H. and Wikramanayake, E. D. (2001). Deccan Thorn Scrub Forests (IMI301). http://www.world wildlife.org/wildworld/profiles/terrestrial_im .html\#drybroad.

Remanandan, P. (1981). The wild gene pool of Cajanus at ICRISAT, Present and Future. Proc. Intl. Workshop on Pigeon-peas, 2: 15-19.
Roubik, D. W. (1992). Ecology and natural history of tropical bees. Cambridge University Press, UK. pp. 526.

Roubik, D. W. (2006). Pollination ecology and the rain forest: Sarawak studies. Springer Science \& Business Media, pp. 308.

Schrire, B. D. (1989). A multidisciplinary approach to pollination biology in the Leguminosae. In: C. H. Stirton and J. L. Zarucchi (eds.). Advances in Legume Biology. Monographs in Systematic Botany from the Missouri Botanical Garden 29, Missouri Botanical Garden Press, St. Louis, pp. 183-242.

Shaukat, S. S. and Burhan, N. (2000). Fecundity, seed characteristics and factors regulating germination of Rhynchosia minima (L.) D. C. Pakistan Journal of Botany, 32: 211-226.

Shivanna, K. R. and Owens, S. J. (1989). Pollenpistil interactions (Papilionoideae). In: C. H. Stirton and J. L. Zarucchi (eds.). Advances in Legume Biology. Monographs in Systematic Botany from the Missouri Botanical Garden 29, Missouri Botanical Garden Press, St. Louis, 157-182.

Small, E. (1988). Pollen-ovule patterns in tribe Trifoliae (leguminosae). Plant Systematics and Evolution, 160: 195-205.

Stirton, C. H. (1981). Petal sculpturing in Papilionoid legumes. In: R.M Polhill and R. $\mathrm{H}$. Raven (eds.). Advances in Legume Systematics. Royal Botanical Gardens, Kew, UK, pp. 771-788.

Tran, V. N. and Cavanagh, A. K. (1984). Structural aspects of dormancy. In: D. R. Murray (ed.). Seed physiology, Germination and Reserve Mobilization, Vol. 2. Academic Press, Sydney, pp. 1-44.

Waller, G. D. (1972). Evaluating responses of honey bees to sugar solutions using an artificial flower feeder. Annals of Entomological Society of America, 65: 857-862.

Westerkamp, C. (1997). Keel blossoms: bee flowers with adaptations against bees. Flora, 192: 125-132.

Yeo, P. F. (1993). Secondary Pollen Presentation. Form, Function and Evolution. Springer, New York, USA, pp. 268. 